\title{
Effectiveness of Food Security Measures for the Population of Perm Region
}

\author{
Bukhtiyarova T.I.* \\ Chelyabinsk branch of the Russian presidential Academy of \\ national economy and public administration \\ Chelyabinsk, Russia \\ e-mail: viola_1_49@mail.ru
}

\section{Demyanov D.G.}

Chelyabinsk branch of the Russian presidential Academy of national economy and public administration

Chelyabinsk, Russia

e-mail: x-line@rambler.ru

\author{
Nemykina Y.S. \\ Chelyabinsk branch of the Russian presidential Academy of \\ national economy and public administration \\ Chelyabinsk, Russia \\ e-mail:july80884@mail.ru \\ Cherdantsev V.P. \\ Federal State Budgetary Educational Institution of Higher \\ Education «Perm State Agro-Technological University \\ named after Academician D.N. Pryanishnikov» \\ Perm, Russia \\ e-mail: cherdantsev.vadim@yandex.ru
}

\begin{abstract}
The food security system is determined by the efficiency of the agricultural sector and should use the best world practices in the use of tools and techniques for managing it. The complexity of the highlighted problem requires the use of a system of indicators that coordinate strategic tasks for the development of agricultural secateurs in rural areas. At the first stage, priority factors that determine the formation of a food security management system are identified. The article proposes an integrative correlation model for food security. Integrative correlation of the assessment is an assessment of the penetrating relationship of the agricultural economy in the Perm region as a whole and the effectiveness of the development of its individual municipalities. The result of the correlation calculation is an effective economic model for assessing food security. Factor analysis has shown that the positions of influence on food security in the context of factors differ in direction, speed, and degree of influence (infrastructure factors, international cooperation, industry factors, institutional environment, natural resource environment, and social environment). At the second stage of the food security management system, the structural organization of the management, the financing scheme, the resource, personnel, and technological security are determined. According to the authors, this approach allows identifying trends in the processes occurring in the agricultural sector and separate territory and making proposals for their adjustment in accordance with the ongoing socio-economic changes. To fully assess the food security system, it is necessary to build and define a variety of analytical criteria that reflect the effectiveness of the main directions of food security. Taking into account priority factors and additional indicators of food security ultimately determines the degree of achievement of food security in the Perm region.
\end{abstract}

Keywords - food security, food resources, crop production, development, analysis, region, territory, agri-food policy

\section{INTRODUCTION}

As a part of the implementation of national security policy, directions for expanding and strengthening the social protection of the population, a particularly important socio economic task is to form a system for providing the population with food. The basic potential of agricultural production plays a significant role in ensuring food security.

Today, for countries with developed economies, the production and processing of agricultural products is considered necessary to ensure political stability, and to meet the most important indicators of national product independence.

The results of the analysis of national and regional particularities and trends in the contemporary agri-food policies allow as generalizations to make the following main conclusion: a single, balanced, harmonious policy of regional and Federal authorities and management eliminates contradictory trends and to successfully implement internal reserves of APK regions that allow the rapid development of the agro-industrial complex of the country, an adequate response to external challenges and the strengthening of Russian positions in world agricultural markets.[9]

Statistical surveys carried out by experts allowed establishing that over the past five years Russian agricultural production and exports have grown by $20 \%$, which has allowed overcoming the import dependence of food and getting the status of a player in the export market.

Food security in the broad sense of the word implies the presence of conditions and factors that support the stability and sustainability of agricultural development in rural areas [9].

In order to analyze this situation, modern metamathematical methods and models are used in order not only to reliably assess food security, but also to make timely organizational, managerial, and economic decisions.

Food resources depending on origin and purpose are classified into a number of groups in the following classes: herbal products, animal products, products support group, the combined products [9]. 


\section{METHODOLOGY}

During the research, we used the following methods: observation, comparison, expert assessments, economic and mathematical methods, and the method of aggregated estimates. The method of aggregated estimates was developed by the authors and is based on the construction of three types of models: economic, mathematical and managerial. Indicative method of assessing economic development and rural territories provided for in legislative acts of the Russian Federation ("RF Government Resolution from May 31, 2019. N 696 "about the approval of the state program of the Russian Federation "Complex development of rural territories" and about modification of some acts of the Government of the Russian Federation").

The indicative assessment of the relationship between the efficiency of the agricultural economy and the development of rural areas is most relevant for industrial-oriented regions, which include the object of research - the Perm region.

Integrative correlation of the assessment is an assessment of the penetrating relationship of the agricultural economy in the Perm region as a whole and the effectiveness of the development of its individual municipalities. The result of the correlation calculation is a constructed economic model for assessing food security.

Using the "body" of integrative correlation, we consider the formation and implementation of conditions for improving the quality of life of the population, within the established standards of life support in the Perm region.

The basic principles of the factor analysis methodology, economic and statistical analysis, and time series theory were used to develop an integrative correlation of the Perm region estimation.

\section{ANALYSIS}

Data on various food groups, product range, volume indicators in natural products, and information on the counteruse of crop and livestock products allow specifying the program of production of agricultural products. That is why when assessing food security it is mandatory and necessary to take into account the conditions of production, the necessary insurance reserves, and the volume of counter-use of agricultural products in agricultural production sectors.

The study analyzes the strategic vectors of livestock and crop production in the context of municipal districts of the Perm region.

A visual representation of the distribution of gross crop collections between the territories of the region (according to 2018 data) is given in figure 1 .

The scheme allows determining the territory of the developed production of agricultural crops. The authors made groupings by main types of agricultural products.

Thus, the largest number of potatoes was produced in Suksunsky district $(321,806 \mathrm{C})$, Perm municipal district (194,703.26 C), Krasnokamsky district (181,861.65 C).

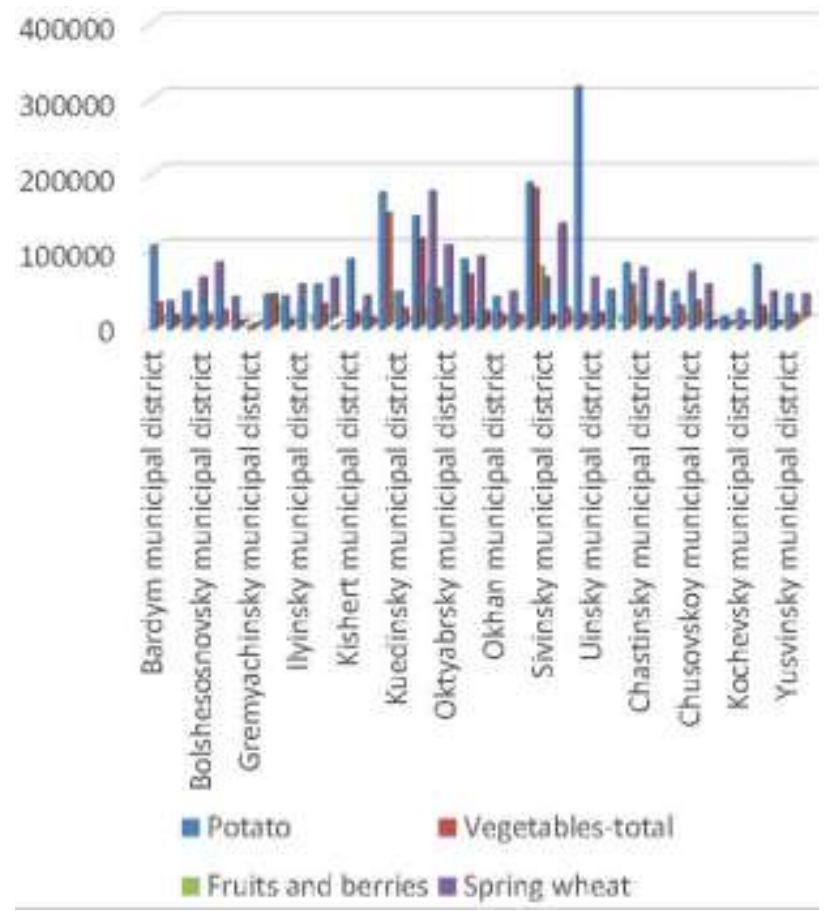

Fig. 1. Distribution of the main crop production crops relative to the municipal districts of the Perm region, calculated by the authors based on data https://permstat.gks.ru / PERMSTAT — state statistics service.

The minimum indicators are Gremyachinsky municipal district $(5,179.46$ C.), Kizelovsky municipal district $(5,209.0$ C.), Kosinsky municipal district (15,059.47 C.).

The "leaders" in the production of fruits and berries in the Perm region are Chernushinsky municipal district $(8,912.19$

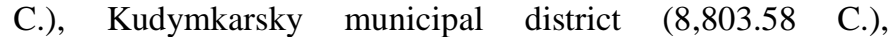
Vereshchaginsky municipal district $(7,459.74$ C.). Lagging behind in this industry group are Chusovskaya municipal district $(11,520.14$ C.), Krasnovishersky municipal district (11,66.5 C.), Gremyachinsky municipal district (1,247.65 C.)

The "leaders" of vegetable production, among the municipal districts are - Gornozavodsky (8,912.19 C.), Elovsky (8803.58 C.), Cherdynsky (7,459.74 C.). "Outsiders" in this area are-Chusovsky municipal district (11,520.14 C.), Krasnovishersky municipal district $(1,166.5 \quad$ C. $)$, Gremyachinsky municipal district (1,247.65 C.).

After analyzing the entire sample of data, we can conclude that in the districts of Krasnovishersky municipal district, Kosinsky municipal district and Gaynsky municipal district, there is the smallest increase in crop production.

The top three "leaders" in this sector of agricultural production are occupied by the Nytvensky municipal district, the Perm municipal district, and the Kungursky municipal district.

After reviewing the data of the crop industry, let us consider the analytical sample for both animal husbandries.

The largest number of livestock and poultry in live weight, produced in Kungursky (6,606 tons), Krasnokamsky (12,245 tons) and Perm (40,557 tons) municipal districts. Less animal products were received in Kizelovsky (33 tons), Gremyachinsky (52 tons), and Gornozavodsky (88 tons) districts. 
In milk production, the three "leaders" are represented as follows: Vereshchaginsky (33,641 tons), Nytvensky (33718 tons), and Kungursky (49,894 tons). Lagging municipal districts are Kizelovsky (196 tons), Gremyachinsky (326 tons), and Gornozavodsky (359 tons).

According to the analysis of indicators of processed products, "developed" (Kungursky, Perm, Kuedinsky) and "developing" (Usolsky, Alexandrovsky, Gornozavodsky) regions are identified.

Production potential in the study is presented in the form of the volume of production that can be produced by municipal enterprises, taking into account the available resources (reflects objective opportunities).

Considering the production resources of animal husbandry in the Perm region in the context of municipal districts, we note that the greatest potential has Krasnokamsky municipal district, Kungursky municipal district and Perm municipal district. In need of development - Gremyachinsky municipal district, Kizelovsky municipal district, Gornozavodsky municipal district.

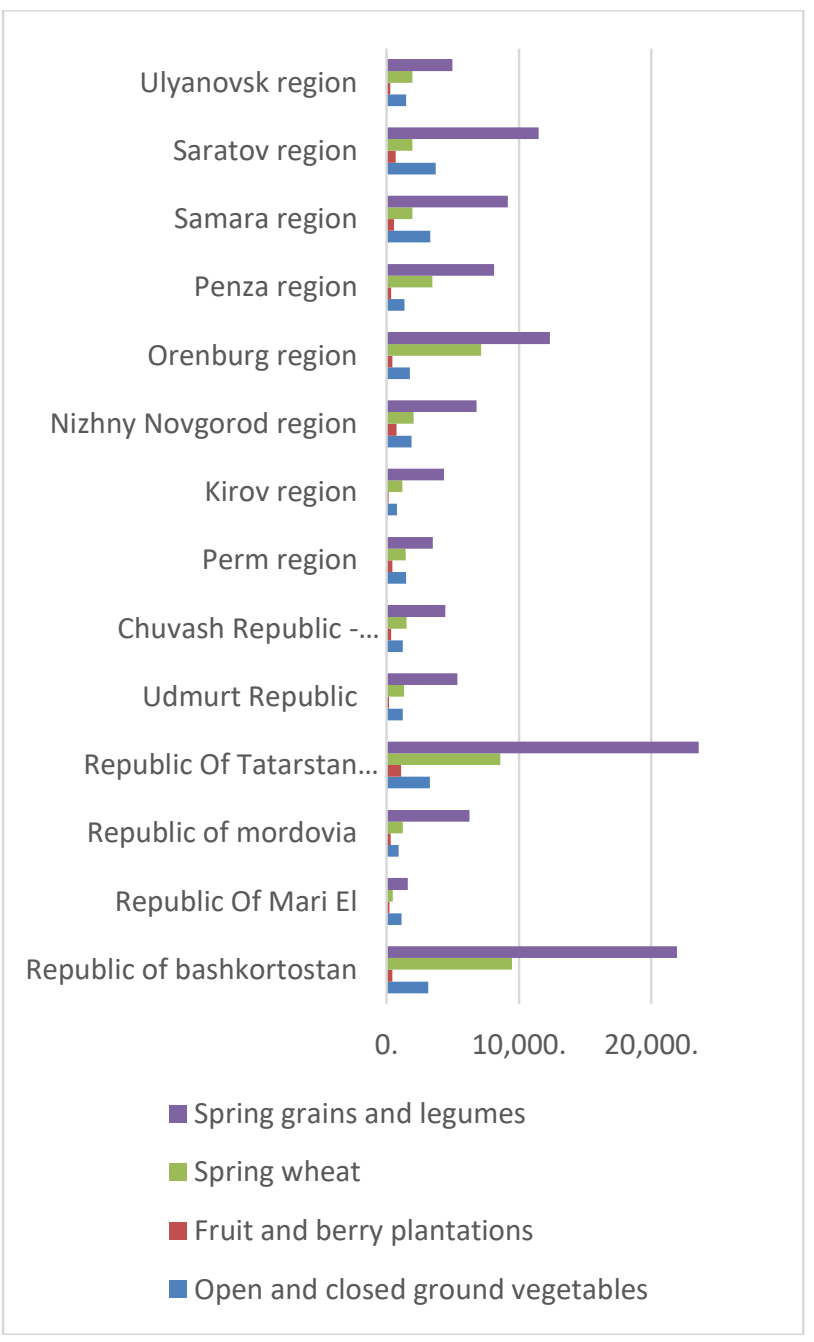

Fig. 2. Distribution of main crops by districts of the Volga Federal district, calculated by the authors based on data https://www.fedstat.ru/ (EMISS state statistics).
For a more complete assessment of the food potential of the Perm region, we will compare its data with the indicators of the Volga Federal district.

The analysis of the main indicators of crop production is clearly presented in the diagram of agricultural industries (figure 2).

Comparing the indicators of production of the main types of food in comparison with the indicators of the Volga Federal district, it is concluded that the Perm region is not a leader in food production. In particular, for the production of potatoes Perm Krai is on the 7th place (2,759.73 tons), the production of fruit crops 5 (442.29 tons) vegetables production 7 $(1,470.04$ tons) in wheat production 10 (1,448.54 tons).

Graphically, the results of the evaluation of livestock production indicators for the Volga Federal district are shown in figure 3 .

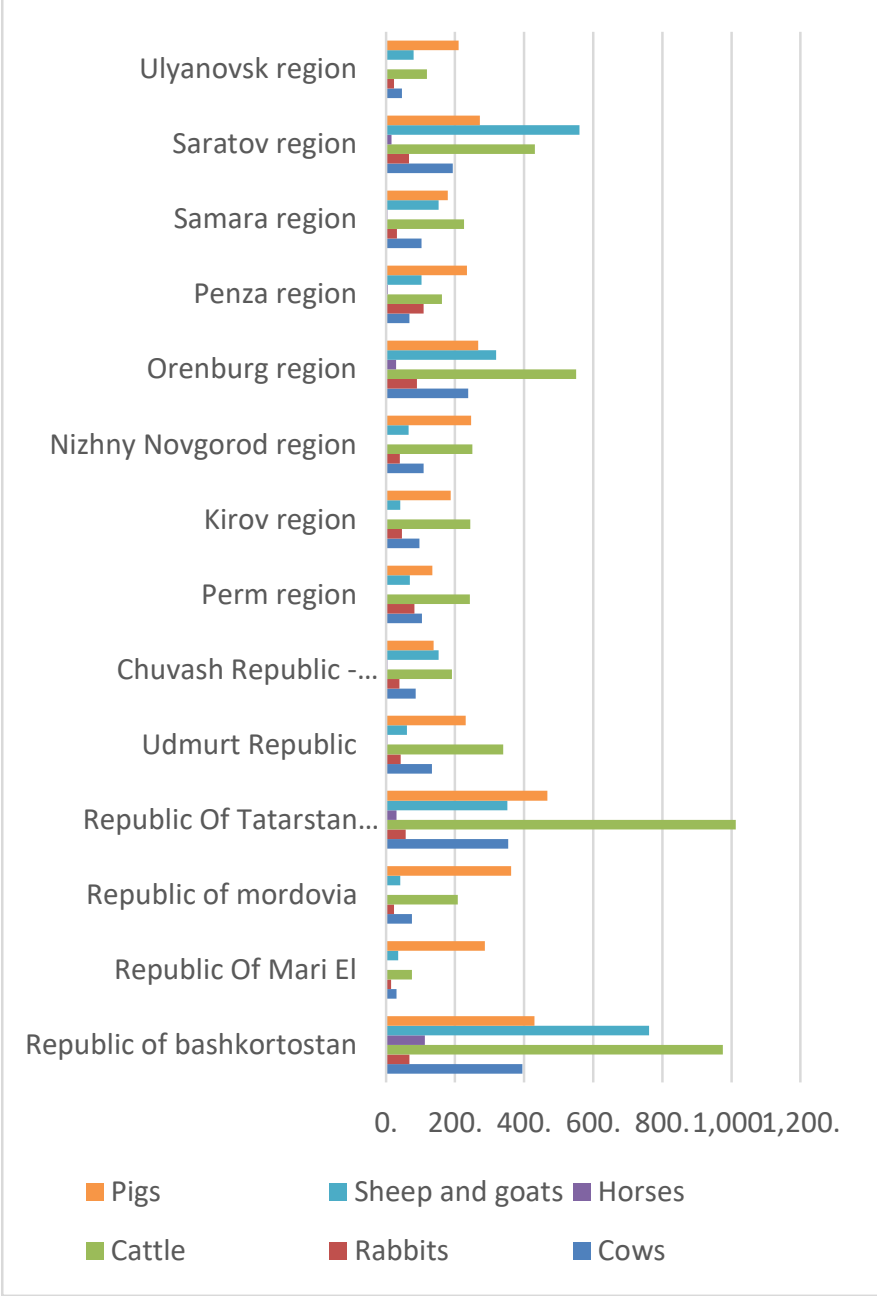

Fig. 3. Livestock and poultry At the end of 2018, heads, by region of the Volga Federal district calculated by the authors based on data https://www.fedstat.ru/ (EMISS — state statistics).

The figure shows that the Perm region needs to reform the agricultural sector of the economy. To confirm this position, consider the indicators of consumption of basic food products per capita in the Perm region and the Volga region as a whole. 
TABLE I. THE CONSUMPTION OF BASIC FOOD PRODUCTS (PER CAPITA), CALCULATED BY THE AUTHORS BASED ON DATA HTTPS://WWW.FEDSTAT.RU/ (EMISS - STATE STATISTICS). THIS IS VALUE OF THE INDICATOR FOR THE YEAR

\begin{tabular}{|c|c|c|c|c|c|c|c|c|}
\hline & $\frac{8}{\pi}$ & 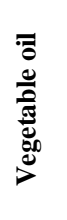 & 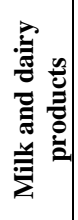 & 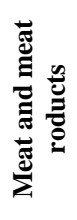 & 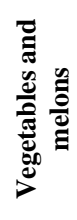 & 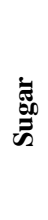 & 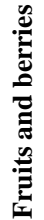 & 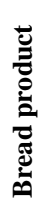 \\
\hline $\begin{array}{l}\text { Volga federal } \\
\text { district }\end{array}$ & 97 & 14,9 & 266 & 72 & 97 & 36 & 54 & 115 \\
\hline Perm region & 67 & 12,7 & 230 & 63 & 82 & 31 & 56 & 115 \\
\hline
\end{tabular}

From table 1, it can be concluded that the consumption of the main types of products in the Perm region is lower than in the Volga Federal district.

The modern problem of research is considered to be the compliance of consumption of basic food products in the amount corresponding to scientifical medical norms (standards).

A sharp decline in agricultural production, the weakening of the material and technical base of the industry and the deterioration of the level of all economic indicators is observed everywhere [10].

In the context of the existing budget deficit, reduced investment in agriculture, and limited available financial resources, the problem of optimal formation and rational use of the material and technical potential of agricultural organizations is of paramount importance [10].

The improvement of the efficiency of agricultural resources use is possible only with innovative and institutional forms of agricultural intensification [10].

In the context of the economic crisis and incomplete agrarian reform in Russia, the program of creating a complex of machines for mechanization and automation, using it as a material basis for improving the efficiency of agricultural industries, has not been implemented.

The imperfection of the control system, accounting for performed operations and produced resource costs has led to a weakening of the mechanism of organization of the production process, increasing the structural imbalances of logistics in agriculture.

\section{DISCUSSION}

The most important requirement for the quality of food supply is the availability and sufficiency of food. The first assumes the uninterrupted flow of food to places of consumption in the volumes and assortment corresponding to demand, the second characterizes the ability of the population to have food in the right quantity and assortment in the retail network and in individual production [9].

According to the authors, the most acceptable method for assessing the food security of the territory is an integrated model for calculating three groups of indicators: the level of food self-sufficiency of the territory, the production potential in basic food products, and the economic availability of food.
To ensure the competitiveness of the agricultural sector, the region's leadership has identified the following urgent tasks: involving a significant amount of unused arable land in circulation; expanding the range of products produced and improving their quality.

The measures to improve the export of products, stimulate the development of small-scale farming in rural areas, and ensure sustainable, integrated development of rural areas and infrastructure in addressing the country's food security program are really necessary. For the agricultural sector of the Perm region, the efficiency of dairy cattle breeding is a priority goal. The management of the subject of the Federation is focused on creating a new image of the territory where the highest quality milk and dairy products are produced [2]

The results of the analysis of the characteristics and trends of formation of modern agro-food policy of the country and regions allow drawing the following main conclusion: a single, balanced, harmonious policy of regional and Federal authorities will help to eliminate conflicting trends and successfully implement regional internal resources APK [2]

Higher-level state authorities, as well as representatives of the business community of the agricultural sector, and rural communities should be involved in holding events [2].

\section{CONCLUSION}

In order to introduce the specification of agricultural production, taking into account the available labor and land resources, it is necessary to obtain additional sources of investment and financial resources from the state and other channels (especially within the framework of public-private partnerships), which are currently actively used in the field of agriculture. These measures will allow getting the status of an agricultural producer, increasing the production of agricultural products, raw materials and food, achieving high performance indicators and stable level of food security.

\section{References}

[1] M.M. Galeev, "Falsification of goods and food security of the state", Financial econ., no. 5, pp. 665-666, 2018.

[2] I. Sandu, V. Krutikov, "Harmonization of regional and Federal policies in the context of foreign economic challenges", Agricult. Econ. of Russ., no. 5, pp. 11-16, 2019.

[3] E.V. Golomanchuk, "General legal characteristics of the nature and features of food security as an element of national security of the state", Agrarian and land law, vol. 11, no. 167, pp. 138-143, 2018

[4] G.G. Faizullin, N.S. Ishchenko, "Food security in the States of the common economic space", pp. 293-301, 2018, Coll. Priorities and prospects of ecological and economic development: regional and municipal aspects [Mater. of the int. sci. and pract. conf.]

[5] Zh.B. Ivanova, "Food security as a guarantee of maintaining the stability of the interests of the individual, society and the state", pp. 162-164 2019, Coll. Modern problems of ensuring environmental and food safety [Mater. of the int. sci. and pract. Conf. of teachers, practical employees, students, undergraduates, and postgraduates].

[6] A.A. Gediev, "Food security as a component of the state's economic security", pp. 120-123, 2018, Coll. Young science-2018 [Mater. of the regional interuniversity sci. and pract. Conf. of students, postgraduates and young scientists]

[7] Zh.V. Rudash, "Food security of the state: the essence, content and conditions of provision", Econ. and entrepreneurship, vol. 6, no. 95, pp. 108-110, 2018. 
[8] P.A. Tabakov, "Food security-an integral part of the national security of the state (on the example of the Chuvash Republic)", Agricult. machinery: maintenance and repair, no. 1-2, pp. 12-22, 2018.

[9] G.R. Taisheva, "Food security of the population in the system of regional regulation" Econ., vol. 1, no. 62, p. 298, 2010.

[10] E.V. Timchenko, Forms the rational use of material resources in agrarian sphere (on materials of Stavropol region agroindustrial complex). Stavropol, 2005.

[11] T.M. Yarkova, "The impact of sanctions on the food security of the state", Bull. of the Prikamsky social Instit., vol. 2, no 80, pp. 140-146, 2018.
[12] T.I. Bukhtiyarova, D.G. Demyanov, Yu.S. Nemykina, "Mechanism of functioning and development of the potential of agriculture in the perm region", Russ. Agricult. Econ., no. 9, pp. 53-58.

[13] G.V. Alekseev, O.I. Aksenova, A.A. Derkanosova, "Optimization of feed for unproductive animals with the help of mathematical modeling" Proc. of the Voronezh State Univer. of Engineer. Technol., no. 1, pp. 28-35, 2015. Retrieved from: https://doi.org/10.20914/2310-12022015-1-28-35

[14] A.N. Ayvazli, "Scientific research on the improvement of commercial banks and application of innovations", Proc. of the Voronezh State Univer. of Engineer. Technol., vol. 81, no. 2, pp. 280-284, 2019. Retrieved from: https://doi.org/10.20914/2310-1202-2019-2-280-284 